\section{The risk of falling}

\author{
L Scalzo ${ }^{*}, M$ D'Andrea, M locco \\ From de Senectute: Age and Health Forum \\ Catanzaro, Italy. 5-7 December 2009
}

The risk of falling represents one of the essential elements of the relationship elapsing between osteoporosis and rehabilitation activity. The damage received from the falls represents the sixth cause of death in persons over 65 years old.

The risk factors for falling have been classified in two great groups: intrinsic factors and not intrinsic factors. Between the main intrinsic factors there are the muscular weakness, the deficit of equilibrium and coordination, the deficits of propriocettivity.

Between the not intrinsic factors there are use of some drugs and the lack of security measures in the domestic atmosphere. The bathroom in particular represents the room of a house where there is a greater risk of fall.

The most recent present studies in literature, such as the appraisal of this risk, must be conducted in multiparametric way. A series of specific semeiological tests exist for the appraisal of some of these risk factors (chair test for the appraisal of the muscular weakness, for example).

This semeiological appraisal can be completed from the data that can be obtained from the administration of FIM scale and ICF classification through the check list in the short form version.

Published: 19 May 2010

\section{References}

1. ICF- Classificazione Internazionale del Funzionamento della disabilità e della. salute Erickson .

2. Meta-analysis: Several strategies prevent falls and subsequent injury in older persons. NHS Center for Reviews and Dissemination and Nuffield Institute for Health 1996.

3. Czerwiński E, Białoszewski D, Borowy P, Kumorek A, Białoszewski A: Epidemiology, clinical significance, costs and fall prevention in elderly people. Ortop Traumatol Rehabil 2008, 10(5):419-28.

4. Berggren M, Stenvall M, Olofsson B, Gustafson Y: Evaluation of a fallprevention program in older people after femoral neck fracture: a oneyear follow-up. Osteoporos Int. 2008, 19(6):801-9.

Cattedra di Medicina Fisica e Riabilitazione - Università degli Studi Magna Graecia di Catanzaro, Italy
doi:10.1186/1471-2318-10-S1-L72

Cite this article as: Scalzo et al:: The risk of falling. BMC Geriatrics 2010 10(Suppl 1):L72.
Submit your next manuscript to BioMed Central and take full advantage of:

- Convenient online submission

- Thorough peer review

- No space constraints or color figure charges

- Immediate publication on acceptance

- Inclusion in PubMed, CAS, Scopus and Google Scholar

- Research which is freely available for redistribution

Submit your manuscript at www.biomedcentral.com/submit
C Biomed Central 